\section{$N$-Persubstituted 3,5-Diaminophenols and 1,3,5-Benzenetriamines and their Protonation}

By $F$. Effenberger and R. Niess $\left.{ }^{[*}\right]$

$N$-Persubstituted 3,5-diaminophenols (2) and 1,3,5-benzenetriamines (3) have not been described previously. We have prepared aminobenzenes (2) and (3) by heating phloroglucinol (1) with secondary amines in an autoclave[1]<smiles>[R]N([R])c1cc(O)cc(N([R])[R])c1</smiles><smiles>[R]N([R])c1cc(N([R])[R])cc(N([R])[Z1])c1</smiles>

The reactions are carried out with an excess of amine (phloroglucinol : amine $=1: 4)$, the molar ratio (2):(3) obtained depending solely on the reaction temperature. The products can be purified by fractional distillation or recrystallization.

\begin{tabular}{|c|c|c|c|c|c|}
\hline Amine used & $\begin{array}{l}\text { Temp. } \\
\left({ }^{\circ} \mathrm{C}\right)\end{array}$ & $\begin{array}{l}\text { Yield } \\
(\%)\end{array}$ & $\begin{array}{l}\text { (2) } \\
\text { M.p. }\left({ }^{\circ} \mathrm{C}\right) \\
\text { (b.p., }{ }^{\circ} \mathrm{C} / \mathrm{mm}\end{array}$ & $\begin{array}{l}\text { Yield } \\
(\%)\end{array}$ & $\begin{array}{l}\text { (3) } \\
\text { M.p. }\left({ }^{\circ} \mathrm{C}\right) \\
\left.\text { (b.p., }{ }^{\circ} \mathrm{C} / \mathrm{mm}\right)\end{array}$ \\
\hline Pyrrolidine & $\begin{array}{r}20 \\
180-200\end{array}$ & $\begin{array}{c}100 \\
-\end{array}$ & $174-185$ & $\overrightarrow{95}$ & $179-181$ \\
\hline Piperidine & $\begin{array}{l}180-200 \\
280-300\end{array}$ & $\begin{array}{l}98 \\
-\end{array}$ & $154-156$ & $\frac{-}{40}$ & 184 \\
\hline Morpholine & $\begin{array}{l}180-200 \\
280-300\end{array}$ & $\begin{array}{l}91 \\
-\end{array}$ & $185-187$ & $\overline{37}$ & $308-312$ \\
\hline Dimethylamine & $\begin{array}{r}130-150 \\
220\end{array}$ & $\begin{array}{l}68 \\
14\end{array}$ & $(148 / 0.008)$ & $\begin{array}{l}22 \\
69\end{array}$ & (131/0.01) \\
\hline
\end{tabular}

With mineral acids the benzenetriamines (3) form definite salts containing 1,2 , or 3 moles of acid.

Depending on the substituents $\mathrm{R}$ and $\mathrm{R}^{\prime}$, stable $N$ - or $C$ protonation products, (4) and (5) respectively, are formed on monoprotonation. $N$-protonation of tripiperidinobenzene $\left[(3), \mathrm{R}\right.$ and $\left.\mathrm{R}^{\prime}=\left(\mathrm{CH}_{2}\right)_{5}\right]$ for example leads to the formation of (4), whilst with tripyrrolidinobenzene $\left[(3), R\right.$ and $R^{\prime}=$ $\left(\mathrm{CH}_{2}\right)_{4}$ ] a crystalline compound of the type (5) is produced. (Physical properties: e.g. (5), $\mathrm{X}=\mathbf{B F}_{4}$, yellow needles. m. $\mathrm{p}$. $254-257^{\circ} \mathrm{C}$ ).
Assignment of structure was based on ${ }^{1} \mathrm{H}-\mathrm{NMR}$-spectroscopic data. The $1 \mathrm{H}-\mathrm{NMR}$ spectrum of tripyrrolidinobenzene hydroiodide $\left[(5), \mathrm{R}\right.$ and $\left.\mathrm{R}^{\prime}=\left(\mathrm{CH}_{2}\right)_{4}, \mathrm{X}=\mathrm{I}\right]$ in $\mathrm{CDCl}_{3}$ showd $\mathrm{H}_{\mathrm{B}}$ as a singlet at $\tau=5.17$ and $\mathrm{H}_{\mathrm{A}}$ as a singlet at $\tau=6.20$ (relative intensities $1: 1$ ).

Particular structural characteristics can be gleaned from the ${ }^{1} \mathrm{H}-\mathrm{NMR}$ spectra of tripiperidinobenzene monoperchlorate $\left[(4), \mathrm{R}\right.$ and $\left.\mathrm{R}^{\prime}=\left(\mathrm{CH}_{2}\right)_{5}, \mathrm{X}=\mathrm{ClO}_{4}\right]$. In polar solvents (e.g. $\left(\mathrm{CD}_{3}\right)_{2} \mathrm{CO}$ or $\left.\left(\mathrm{CD}_{3}\right)_{2} \mathrm{SO}\right)$ the three nuclear protons appear as a singlet $2 t \tau=3.6$, whilst the proton attached to the nitrogen (whose presence can be seen only on integration) indicates rapid proton exchange among the amino groups. On the other hand, in $\mathrm{CDCl}_{3}$ this proton is fixed on an amino function and the signals of the three nuclear protons are widely separated in the spectrum $(1 \mathrm{H}$ at $\tau=2.10[\mathrm{~N}-\mathrm{H}]$, $2 \mathrm{H}$ at $\tau=3.38$ and $1 \mathrm{H}$ at $\tau=4.63$ ). A meta coupling of the ring protons $\mathrm{H}_{A}$ and $\mathrm{H}_{B}$ was not observed. The comparable $N$-methyl compound $\left[(6), \mathrm{R}\right.$ and $\left.\mathrm{R}^{\prime}=\left(\mathrm{CH}_{2}\right)_{5}, \mathrm{X}=\mathrm{ClO}_{4}\right]$, however, shows only a small amount of splitting of the nuclear protons ( $\tau$-values centered at 3.5 ) and a distinct meta coupling $\left(J_{\mathrm{AB}}=2 \mathrm{~Hz}\right)$.

We conclude from the NMR spectra that there is a strong electronic disturbance of the aromatic $\pi$-electron system in tripiperidinobenzene monoperchlorate. An alternative to the benzenoid structure (4) is a valence isomer with a "Dewar structure"; although this would certainly agree with the NMR spectrum, we have no other evidence to support this structure.

Further investigations, in particular X-ray structural analysis of the tripiperidinobenzene monoperchlorate, are in progress.

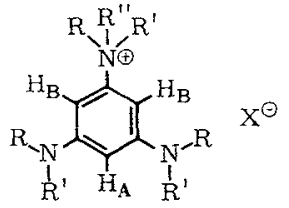

(4), $\mathrm{R}^{\prime \prime}=\mathrm{H}$

(6), $\mathrm{R}^{\prime \prime}=\mathrm{CH}_{3}$

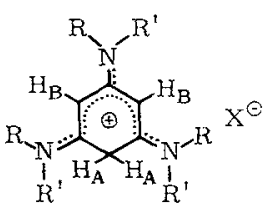

(5)
Received: August 11th, 1966; revised Sept. 9th, 1966 [Z 320 IE] German version: Angew. Chem. 78, 1100 (1967)

$\left[{ }^{*}\right]$ Dr. F. Effenberger and R. Niess

Institut für Organ. Chemie

der Techn. Hochschule

Azenbergstr. 14/16

7 Stuttgart (Germany)

[1] The preparation of the aminobenzenes was reported at the Chemiedozententagung in Würzburg on April 29 th, 1966. 